\title{
Marriage as a choice or duty: Considering Nigerian Christians' attitude to singlehood from the biblical perspective
}

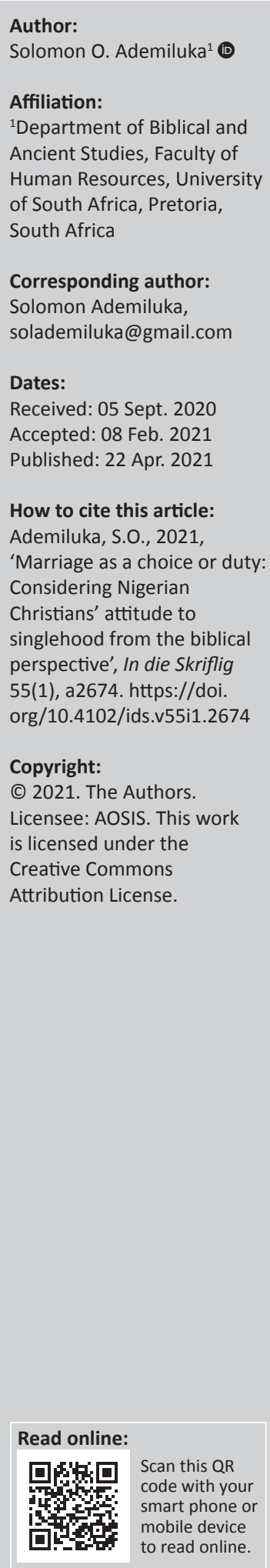

Of recent in Nigeria, there has been a considerable increase in the rate of involuntary singlehood, particularly among women. It constitutes a major constraint for Christians because of the general perception that the Bible commands everyone to marry - the belief which they derive from Genesis 1:28 and 2:18, 24. However, most people who have this notion, hardly take cognisance of Paul's preference for celibacy as in 1 Corinthians 7 . The situation is compounded by popular Christian preaching and an attitude which favour marriage against singlehood. The result is the frantic desperation among Nigerian Christian women to get married. Against this background, this article attempted to ascertain if marriage is necessarily an obligation for Christians, and appraised Nigerian Christian single women's desperation for marriage against the understanding of the Genesis and 1 Corinthians passages as presented in this study. As the author of this article, I did exegeses of the texts and interacted with relevant material on singlehood and its constraints, especially in relation to Nigerian women. The work found that the Genesis passages from which is derived the perception that marriage is obligatory for all, are largely misunderstood. Hence, they are not in contention with 1 Corinthians 7 which views marriage and celibacy as equal. In view of this, the article considered Nigerian Christian single women's desperation to get married as unnecessary. For this reason, it advised the church in Nigeria to imbibe the biblical perspective of equality of marriage and singlehood, and inculcate it in its members.

Contribution: The article is a contribution in the context of the theology of marriage, and of particular relevance in Nigeria where most Christians still have the belief that marriage is a moral duty for all.

Keywords: singlehood; Genesis 2:18, 24; 1 Corinthians 7; celibacy; marriage and procreation; between marriage and singlehood; Christians and marriage; Nigerian Christian single women; the church and single women.

\section{Introduction}

In the traditional African society, marriage is an obligation for every normal person. The most important reason why Africans get married, is the desire to have children. In the past, the most important reason people wanted to have children was the need to get heirs who would sustain the paternal lineage. Today, however, every African wants to marry and have children just because it is perceived as the normal course of life.

Nevertheless, in contrast to this wish, in contemporary Nigeria involuntary singlehood has since been on the increase, especially among the womenfolk. In this country, singlehood among women may refer to several groups. There are some women who have had children with certain men with whom they maintain some form of attachment while remaining formally unmarried. In some of such cases, there is no attachment at all, in which case such women become single mothers. In most of the ethnic groups in Nigeria, neither of these cases are still socially unacceptable. What is acceptable, and the desire of every woman, is formal marriage, which really means a man asking her hand in marriage and paying the bride price to her parents. ${ }^{1}$ In this article, the focus is particularly on women at the age of 30 and above who are childless and who have never been married before, excluding celibates and those who are unmarried due to some physical handicap. This group of women go through a life that is largely characterised by a feeling of incompleteness and the desperation to get married. Part of the burden of this group of women who are Christians is the feeling of some guilt due to the perception of many that the Bible commands everyone to marry and procreate - the idea that is often derived from Genesis 1:28 and 2:18, 24.

1.In other words, marriage does not have to take the form of wedding in the church, mosque or court. 
However, many people who have this perception hardly consider Paul's preference for celibacy in 1 Corinthians 7.

Therefore, against the background of desperation for marriage among Nigerian Christian women, this article attempts to ascertain whether, from the biblical perspective, marriage is necessarily an obligation for Christians. From the biblical point of view, is marriage a choice or a duty?

The target population is Nigerian Christians, especially those healthy women who remain single involuntarily. This article employs the descriptive and exegetical methods. It uses the descriptive approach in the study to the constraints of singlehood among Nigerian Christians, and the exegetical method for the examination of the Genesis and 1 Corinthians passages. It begins by examining the significance of marriage in African culture, from which it proceeds to discuss the constraints of singlehood among Nigerian Christians. Finally, the article attempts the exegeses of the relevant texts in relation to marriage.

\section{The significance of marriage in African culture}

The significance of marriage in the traditional African society is best understood in the words of Mbiti (1991) that:

[Marriage is considered] as a sacred duty which every normal person must perform, and ... anybody who, under normal conditions, refuses to get married, is committing a major offence in the eyes of the society ... [W]ithout marriage a person is not considered to be complete, 'perfect', and truly a man or a woman. (cited in Oderinde 2013:166-167; cf. Mbiti 1969:104)

In Nigeria, 'prolonged non marriage ... and permanent non marriage ... has no place in [the] socio-cultural system' (Ntoimo 2012:1). One reason why marriage is thus important is that 'through marriage and childbearing, humankind is preserved, propagated and perpetuated ... Therefore, marriage and childbearing are ... at the very center of human existence' (Mbiti 1969, cited in Kyalo 2012:214). In Africa, marriage and childbearing are not just closely linked, but, in fact, marriage is constituted primarily for the purpose of procreation. Mbiti (1969:132) states that in Africa 'the supreme purpose of marriage is to bear children to build a family [hence] if there is not yet a child in the marriage people do not consider it to be a marriage'. In fact, in the traditional setting, the birth of the first 'child marked the consummation of a sustained and crisis-free marriage' (Ojua, Lukpata \& Atama 2014:44). Writing on the Igbo of southeastern Nigeria, Oforchukwu (2010) states that:

$[T]$ o be childless is the greatest calamity that can befall a woman. For an Igbo man, producing children, especially male children, is important to continue the family lineage; otherwise, the family would become extinct. (p. 38)

Uchendu (1965) depicts the connection between marriage and childbearing in Africa when he states that 'a woman's glory is her children, and to have children, she must have a husband' (cited in Ntoimo 2012:1).
Apart from the factor of the perpetuation of life, Africans exhibit a natural passion for children and childbearing for which reason everyone sees marriage as an obligation. The passion is seen, for instance, in the Yoruba saying, 'Omo l'okun, omo n'ide; enia t'o wa saye ti ko bimo, aye asan lo wa' [A child is a coral bead; a child is silver; a person who has none has not lived a fulfilled life] (Makinde 2004:167, [author's translation]). This saying equates a child with okun [beads] worn by kings and chiefs as a symbol of royalty and authority. It therefore means 'that a child confers on his/her mother the power to exercise authority in her husband's home' (Makinde 2004:167). For a woman, then, it is only her children that assure her of a matrimonial home. Comparing a child with silver also depicts the preciousness of children. It is therefore clear why singlehood remains a matter of concern to Africans, particularly women. The section below examines the constraints of singlehood among Nigerian Christians.

\section{Nigerian Christians and the constraints of singlehood}

Christian attitude to singlehood in Nigeria is influenced not only by the factors discussed above, but also by the attitude of the church towards marriage. Attitudes towards marriage in the church itself have fluctuated over time. Agana (2018:90) states that during the 'medieval era there was a pervasively negative attitude towards marriage'. According to Augustine, as there was 'no sexual drive before the Fall, marriage was a device of God to contain that lust within a framework that would make it less morally repugnant' (Agana 2018:90). Agana (2018:90) further explains that, for centuries, Augustine's perception was the norm in 'Roman Catholic theology in which celibacy and virginity were more highly regarded than marriage'. Following Augustine, Aquinas insisted that celibacy was preferable to marriage. However, during the Reformation, Martin Luther greatly challenged this traditional notion of marriage. Condemning celibacy, Luther declared that marriage was 'an outward and spiritual sign of the greatest, holiest, worthiest and noblest thing that ever existed' (O'Reggio 2012:202). Following Luther, Calvin ensured 'social and legal precepts for the practice of marriage as a social institution' until the end of the monarchy in Geneva (White 2009, cited in Agana 2018:92). This marked the beginning of the general Christian attitude towards marriage in modern times. In Africa, particularly due to the 'superlative views of the sanctity and usefulness of marriage within much of Christian theology ... celibacy and singleness are often frowned upon especially in Protestant churches' (Agana 2018:92).

Hence, in a cultural context such as Nigeria in which being unmarried is an aberration, the enormity of the constraints of singlehood cannot be over-emphasised.

The term singlehood refers to the state of being single and especially unmarried' (Singlehood 2020). When applied to women (Ntoimo 2012): 
[Singlehood] describes older never married women, who are past conventional age for marriage ... [B] ecause most women marry for the first time in their 20s, many demographers and family scholars use the age marker of 30 or 35 years to distinguish younger never married women from spinsters. In societies where marriage is strongly associated with motherhood, marriage after age 30, which is the upper limit of the most fecund years, for women, is considered late. (p. 1)

Among most ethnic groups in Nigeria, marriage for females is usually expected before or at age 30 , by which time reasonable pressure for marriage would have begun to mount on the singles concerned (Isiugo-Abanihe 2000; NPC 2009, both cited in Ntoimo 2012:2). Oderinde (2013:168) observes that 'pushing the age of marriage into the late thirties and higher is now an increasing trend in the [Nigerian] society'. Isiugo-Abanihe (2000) also attests to the 'increase in female age at first marriage among certain socio-cultural groups in Nigeria' (cited in Ntoimo 2012:2). One major reason for late marriage of both men and women in Nigeria is the downward turn of the economy over the years, which has rendered most male youths unemployed. Without stable jobs, most 'young men do not have the necessary resources to pay [the bride price]' and to cater for family (Zwang 2004:30; cf. Oderinde 2013:168). The women's situation is made more complex by the transformation from the traditional pattern by which the choice of spouse was made 'by parents to the more individualistic pattern based on self-selection' (Ntoimo 2012:1). Added to this is the fact that a woman has to wait for men to ask her hands in marriage, as the 'culture prohibits a woman from making the first move' (Agazue 2016:7).

Nonetheless, there are other nuptial behaviours on the part of young women which cause delay in marriage or non-marriage. According to Oderinde (2013:169), some ladies take undue time to enjoy spinsterhood, believing that being married would rob them of the enjoyment. Some Christian young women rely on divine guidance for the choice of marriage partners; most often waiting for 'vision, prophecy and dreams alone. So they wait endlessly to see vision or dream about the right man' (Oderinde 2013:168). In Nigeria, as in Africa at large, the general attitude towards singles, especially women, is not at all pleasant. As the society has the perception 'that every normal person must get married ... a single adult person is not only unacceptable, but he/she also becomes a bad example in the community' (Baloyi 2010:725). Hence, single persons are 'stigmatized and seen as having moral or spiritual problems' (Ntoimo \& Isiugo-Abanihe 2013:2001). Unmarried women are usually avoided by the married, treated with disdain and looked upon as pitiable people (Oderinde 2013:169). They are often placed on watch by married women, suspecting that they might be making advances to their husbands (Baloyi 2010:735). It is no surprise, then, that most unmarried women show symptoms of withdrawing from society, among other psychological problems. According to Koons and Anthony (1991:115), ' $[t]$ hey very often will withdraw into themselves, into their homes, and become reclusive, rejecting all attempts of others to reach out to them'. Manasra (2003:424) states that women who are unable to marry 'might feel useless, hopeless, worthless, and desperate [which] could lead to self-pity, selfhatred, and negative self-esteem'. Shuzhuo et al. (2010) are therefore correct when they assert that:

Singlehood is a state of frustration, and even of deprivation, for which it is difficult to find socially acceptable compensations, [being excluded from] having children, living with a partner, having sexual relations. (p. 679)

In a culture such as Nigeria, in which it is the man that must make the move to find a wife, while single men may approach women to seek their hands in marriage, the main method by which single women attempt to change their status is by seeking divine intervention. ${ }^{2}$ In this regard, Agazue (2016:7) notes that single 'women face double jeopardy' for obvious reasons. Firstly, it is the fact that the 'biological clock' seems to tick faster for women and thus puts them 'under intense pressure to get married as soon as possible'.

\section{Secondly (Agazue 2016):}

The culture that prohibits childbearing outside marriage or single parenting affects women more than men. This makes women more desperate for marriage because they may not want to bear the shame associated with childbearing outside marriage or single parenting. If a man impregnates a woman outside marriage, the woman bears greater consequences than the man. For example, the woman is the one to carry the pregnancy and bring up the child with her resources and in her own home while the man may remain almost invisible. (p. 7)

This explains single women's desperation and their patronage of the divine avenues. Seeking for husband through divine intervention comes against the backdrop of the perception that having delay in marriage, like any other misfortune, is a spiritual problem. According to Oderinde (2013):

It is believed that the [persons affected] have been cursed, maybe by man or spirits, for one reason or the other. Some are believed to have relationships with some invisible personalities, [such as] spiritual husbands or spiritual wives, and may not be able to get married in the physical realm until such relationships are broken through prayers and special deliverance. (p. 168)

Cashing in on such women's belief 'that they are spiritually chained [and] can only attract their life partners' through divine means, some pastors and prophets have exploited many unmarried women both financially and sexually' (Agazue 2015:22). But, from the biblical perspective, is the desperation for marriage really necessary? In other words, must everyone get married? In the following section, the article attempts to answer this question.

\section{Marriage as a choice or duty: Considering Genesis 1:28 and 2:18, 24 and 1 Corinthians 7}

Basically, three passages in the Old Testament, namely Genesis 1:28 and 2:18, 24 are often regarded as making

2.One is aware that these days, single men and women do advertise themselves on radio and television, as well as social media for marriage, but this is yet to be a popularly accepted method of getting marriage partners in Nigeria. 
marriage an obligation for everybody, particularly Christians. However, people rarely consider the apparent antithesis in 1 Corinthians 7. Here these passages will be examined with a view to determining their intent in relation to marriage.

\section{Genesis 1:28}

The phrase 'Be fruitful and multiply' in Genesis 1:28 is often interpreted as a command for every individual to have children, which indirectly implies an injunction to marry, as 'we cannot think of ... procreation in abstraction from marriage' (Murray 1957, cited in Magnuson 2000:27). Wenham (1987:33) believes that Genesis 1:28, coming after Genesis 1:27 ('Male and female he created them'), indicates 'the divine purpose of marriage'. In Genesis 1:26-28, 'the highpoint and goal has been reached toward which all of God's creativity from vs. 1 on was directed', that is, the creation of the humankind (Davidson 1988:5). After creating mankind in Genesis 1:27, verse 28 states:

And God blessed them, and God said to them, 'Be fruitful and multiply, and fill the earth and subdue it; and have dominion over the fish of the sea and over the birds of the air and over every living thing that moves upon the earth'. (RSV) ${ }^{3}$

The concern of this article, however, is with the phrase 'Be fruitful and multiply' (פרו ורבו in Hebrew). פרו is the qal imperative of the verb פרה , meaning 'to bear fruit'.

According to Koehler and Baumgartner (2000), פרה refers specifically to 'the fruit of the vine, or of the fig tree but more importantly to the fruit of the womb, resulting from intercourse between the male and female' (cited in Ahiamadu 2010:99). רבר is also the qal imperative of the root רבה - 'to be many' or 'to be great'. The root 'is a word used mostly in quantitative contexts, but sometimes also in a metaphorical sense' meaning 'to have many children' as in 1 Chronicles 7:4 (Ahiamadu 2010:100). There appears to be no controversy about the translation of the phrase, as many English versions render it as 'Be fruitful and multiply' (e.g. RSV, NRSV, KJV, NJKV, NASB). The NIV translates it as 'Be fruitful and increase in number', which is not in contention with these other versions. According to the narrator, 'Be fruitful and multiply' were God's first words to mankind. The same words are repeated to Noah after the Flood (Gn 9:1, 7). They appear in similar forms again to Abraham (Gn 17:6) and to Jacob (Gn 35:11). Davidson (1988:10) opines that it is clear from this phrase that 'one of the primary purposes of sexuality is procreation ... Procreation is shown to be part of the divine design for human sexuality.'

Magnuson (2000:26) states that, in Jewish tradition and interpretation, 'Be fruitful and multiply' 'is considered to be a moral imperative, a religious duty that is meant to channel sexual passion for the purpose of the perpetuation of humankind'. According to Moss and Baden (2015), perhaps

3.The English Bible versions used in this article are abbreviated as follows: Revised Standard Version (RSV); New Revised Standard Version (NRSV); King James Version (KJV); NeW King ames Version (NKJV); New Amersion (NRSV); King Jams: Revised (KJV); New King James Version (NKJV); New American Standard Bible (NASB); New International Version (NIV); Today's English Version (TEV); English Standard Version (ESV); New American Bible (NAB); New Jerusalem Bible (NJB); New Living Translation (NLT). because they were given to the 'first two men', Adam and Noah:

$[F]$ or thousands of years, these words have been understood as a divine imperative to each and every individual ... to produce offspring ... If one chooses not to bear children, then one could be seen as violating a direct divine command ... If one is unable to bear children, one is considered cursed. (pp. 70, 72)

Ryan (2005:69) most likely had Genesis 1:28 in mind, among other passages, when he stated that the interwoven symbolisms of judgment, blessing, and mystery [in some Bible references make] some believe that they are being punished by God' if they do not have children. Omeike (2017:19) most probably attests to a reaction to the Genesis text among the Igbo of southeastern Nigeria when he states that their natural inclination for children 'has been reinforced by biblical and ecclesial emphasis on fruitfulness'. Furthermore, in a study conducted by Okonofua et al. (1997:211) in southwestern Nigeria, people gave several reasons for wanting to have children, among which was 'to obey the command of God to "go forth and multiply"'. This reason is most likely an incidental reference to Genesis 1:28, because the respondents in the study were composed 'largely [of] Christian population' (Okonofua et al. 1997:211).

According to Magnuson (2000) regarding the grammatical construction and the context of Genesis 1, verse 28 indeed lends itself to a reading as a command. He states:

[T] he statement is in the form of an imperative and it fits with the pattern of 'command and execution' throughout [the chapter]. [For instance,] God creates the 'expanse' (1:6-8), and commands the celestial bodies to fill it (1:14-18); he creates the sky (1:6-8) and the seas (1:9-10), and commands the birds and the sea creatures to fill them (1:20) ... The will of the Creator is made clear through His command, and His creatures are left to carry out His command. It is not difficult, therefore, to understand why procreation is taken as a moral command, a creation mandate or religious duty. (p. 27)

However, as Moss and Baden (2015) rightly observe, 'Be fruitful and multiply' is better read as a blessing rather than a command. In the first place, neither Noah nor Jacob had children again after they received the words. 'If God's words are understood as a command, then we would have to conclude that both Noah and Jacob are guilty of disobeying the divine will' (Moss \& Baden 2015:74). It is also important to note that 'the imperative is grouped with others, including filling, ruling, and subduing the earth, which are not promoted as moral duties' (Magnuson 2000:28). Moreover, the same words are said to the fish of the seas (Gn 1:22), which are 'obviously not intended to become responsible for their reproduction' (Daube 1977:3). Whereas, if the text is read as a blessing, the question of obedience or disobedience does not arise; instead, the responsibility resides with God to fulfil his words. As Magnuson (2000) puts it:

[W]hile human beings can demonstrate an openness to procreation, it is God alone who creates life. Since life is a gift from God (Ps 127:3), understanding procreation as a command may place too much emphasis upon human procurement of God's blessing. (p. 28) 
In the words of Moss and Baden (2015):

There are abundant reasons, therefore, for rejecting the common, if not universal, view that the words 'be fruitful and multiply' should be taken as a divine imperative to procreate, one that can be either obeyed or disobeyed. (p. 74)

Furthermore, the blessing of children in Genesis 1:28 should not be read as applying to individuals or 'something that is passed down genetically' from Adam or Noah (Moss \& Baden 2015:75). For, if it were so understood, there would have been no need to repeat it to Abraham and Jacob. The blessing is best understood in light of its 'functional parallel' in Genesis 12:2: 'And I will make of you a great nation, and I will bless you, and make your name great, so that you will be a blessing' (RSV; cf. Moss \& Baden 2015:75). In other words, the promise of children was not necessarily for Abraham and Jacob as individuals, but had in mind 'the people who, far in the future, will descend from those who are blessed' (Moss \& Baden 2015:75). Therefore, although couched as an imperative, the phrase Be fruitful and multiply is not a divine command for every individual to have children. Monroe and Monroe (2005:50) put it succinctly as, 'Children are a blessing, but they are not promised to us individually.' If Genesis 1:28 is not a command that everyone must have children, then it does not imply an injunction that everyone must marry.

\section{Genesis 2:18, 24}

It is common knowledge that 'ministers and lay preachers [often preach] on the basis of Genesis 2:18, 24 that marriage is incumbent on all who can' (Agana 2018:90). Commenting on Genesis 2:24, Taylor (2010:1) states that 'marriage is a creation ordinance, laid down by God for all humans from the beginning'. In Nigeria, relying on Genesis 2, most Christian preaching takes for granted that everyone should marry, although oftentimes with emphasis on monogamy, because that was how God ordained marriage from the beginning. From the beginning, God desired that man should have only one wife, and this 'account of the creation of Eve has remained the benchmark for man to live by' (Igbokwe 2011: n.p.). Some Nigerian biblical scholars also believe that Genesis 2 is a basis for marriage, 'as a divinely instituted union [but] involving only a man and woman' (Uzoma \& Okoye 2010:82; cf. Adamolekun 2006:138-150).

Genesis 2:18, 24 must be examined in the context of verses 18-24 - the unit which is often interpreted from the perspective of marriage. Many authors have found in Genesis 2:18-24, not only God's design for marriage, but also the description of the original marriage (Cole 1995: n.p.). In view of the conclusion in Genesis 2:24 that a man shall leave his parents and cleave to his wife, Jerome (2016:528) affirms that ' $t]$ he passage has been recognized as a narrative on the divine institution of marriage and the beginning of human family'. As Wenham (1994:62) sees it, ‘[ $t$ ]he charming tale of God creating woman out of Adam's rib and then presenting her to him as if at a wedding, sums up beautifully many of the key biblical ideas about marriage'.
Scholars have also identified certain motifs in the narrative which lend it to interpretation from the perspective of marriage. The situation that led to the creation of the woman was man's loneliness, which God observed as 'not good' (Gn 2:18) - a statement that indicates the need for a companion (Birch et al. 2005:46). The Lord God then went ahead and created a companion for the man, described in the phrase [lit. a helper as opposite to him] which is variously translated as 'an help meet for him' (KJV), 'a helper fit for him' (ESV; RSV), 'a helper suitable for him' (NASB; NIV). The key word, then, is 'helper' (עזר), the term which is frequently used in the Old Testament to designate 'help', 'support', 'helper' (Schultz 1980:661). Genesis 2:21-22 state that woman was formed from man's צלע. Although most English versions render the word rib, there is evidence that it also refers to the side of an object such as a hill (2 Sm 16:13) or the ark $(E x 25: 12,14)$. It has therefore been plausibly suggested that in this passage refers to 'side' rather than 'rib' (Birch et al. 2005:45; Efthimiadis-Keith 2010:59; Hartley 1980:768). Genesis 2:23 continues with the prerogative given to man in verse 19 to name all the creatures that the Lord God had formed. Here he gives her the name אשיה [woman] 'because she was taken out of Man' (איש), but in the fall narrative (Gn 3:20) he gave her another name, Eve (חוּה). Hooke (1982) points out that:

[T] he act of naming is a very important symbol [because $]$... to know the name of a person or thing is to know its essential nature and to have power over it. (p. 179, cf. Merril 1991:15)

In light of this, the act of naming the woman by man means that he has power over her as over the other creatures. Efthimiadis-Keith (2010:59) however notes that this act 'does not indicate subordination or inferiority on her part'. After the man's exclamation: 'This is now bone of my bones, and flesh of my flesh: she shall be called Woman, because she was taken out of Man' (Gn 2:23 [KJV]), comes the comment in verse 24: 'Therefore shall a man leave his father and his mother, and shall cleave unto his wife: and they shall be one flesh' (KJV).

The first part of Genesis 2:18 is often employed as a basis for the position that marriage is obligatory for all: 'It is not good that the man should be alone.' Agana (2018:93) notes that, in order to give 'credence to the theory of universal obligation of marriage', many interpreters often omit the article; thereby rendering it as 'It is not good for man to be alone.' In this way, the Christian community has reverted to (Agana 2018):

[T] he extreme opposite of the patristic era when marriage was considered a necessary evil, fit only for procreation and for those who could not contain the lust of their flesh. (p. 93)

This contemporary Christian perception about marriage is fostered by many Bible commentaries. For example, commenting on Genesis 2:18, the Adam Clarke Commentary states that:

[M]an was made a social creature [hence] it was not proper that he should be alone [that is] without a matrimonial companion. Hence, we find that celibacy in general is a thing that is not good, whether it be on the side of the man or of the woman. (Studylight. org 2001-2020a: n.p., [author's italics]) 
John Calvin's Commentary admits that the pronouncement of 'not good to be alone' was made on Adam, but that the declaration should be regarded 'as a common law of man's vocation, so that everyone ought to receive it as said to himself' (Studylight.org 2001-2020a: n.p.). These commentaries, then, address Genesis 2:18 to mankind in general. However, this approach does not represent the intent of the passage - the fact which is buttressed by the 'widespread translational consensus on definiteness in 2:18' (Agana 2018:94). Apart from a few such as the Darby and Douay-Rheims, most of the English translations (e.g. NIV, NASB, ESV, NLT, KJV \& RSV) retain the article, having 'the man'. The Masoretic Text (MT) therefore refers to 'a particular man, the first man created by God' (Lussier 1956:137). As Agana (2018:103) puts it, in Genesis 2:18, 'we are dealing with a definite referent rather than a generic one'. This means that this verse is not applicable to every person, and therefore cannot be used to support the claim of a command of marriage for everyone.

Commenting on Genesis 2:24, the Adam Clarke Commentary asserts that 'God made the woman for the man, and thus he has shown us that every son of Adam should be united to a daughter of Eve to the end of the world' (Studylight.org 2001-2020b: n.p.). As Warner (n.d.) rightly observes, there are divergent views on the meaning of Genesis 2:24, but many agree that it is an aetiology - a text that attempts to explain the origin of a practice or custom. Davidson (1973) identifies 'Genesis 2:24 as the first in the series of this literary figure' (cited in Jerome 2016:529). It is also clear that in Genesis 2:24 'the writer shifts from a sequential narrative format to make an evaluative reflection' (Agana 2018:104). To this end, many scholars agree that Genesis 2:24 was added by an 'editor working later than the primary author of Genesis 2' (Warner n.d.: n.p.). As Luck (2009: n.p.) puts it, 'Genesis 2:24 ... appears as an editorial comment made as the writer reflected upon the account of the creation of Eve'.

Genesis 2:24 is better understood when read in intimate connection with Genesis 2:23 with its focus on 'the extremely powerful attraction of the sexes to each other' (Jerome 2016:529). As aptly described by Jerome (2016):

The author of Genesis 2:18-24, attempting to give a reason for this strong reciprocal attraction of man and woman ... sees a clue to this natural human experience in the way God created the woman by using the rib of the man. Being originally one, they must naturally come together. A man leaves his father and mother and clings to his wife in order to effectively achieve this union. (p. 529)

Thus, in a way, the intent of the author in Genesis 2:24 is to show the reason for the natural attraction between man and woman. It is because, originally, 'the woman is bone of man's bone and flesh of his flesh' (Cole 1995: n.p.). It is also noteworthy that the narrative introduces gender distinction in Genesis 2:23 in the creation of woman - the differentiation that is carried furthermore, specifically in verse 24 , in the use of איש [man instead of אדם, which refers to the male category, and אשיה [woman; wife], denoting the female category. In this way, Genesis 2:24 intends to explain how the male-female relationship 'maintains the ontological unity of humanity through' the marital relationship (Agana 2018:106). As the male-female distinction is introduced in the singular (a man ... to his wife), it is logical to deduce from Genesis 2:24 that 'marriage should be a heterosexual union between a male and a female; not that it must be between all men and all women' (Agana 2018:106).

Nonetheless, the intent of Genesis 2:24 is still better understood when the issue of the appropriate tense is resolved. The translation in the simple present tense states, 'Therefore a man leaves his father and mother and cleaves to his wife, and they become one flesh' (e.g. RSV; NLT; NAB; $\mathrm{NJB}$ ). As already shown, the other in the future tense reads, 'Therefore shall a man leave his father and his mother, and shall cleave unto his wife, and they shall become one flesh' (e.g. $\mathrm{KJV}$; NIV; ESV). What is rendered in the future tense is the Hebrew imperfect - the two key verbs being עזב [to leave] and דבק [to cleave]. Some scholars claim that the imperfect may sometimes indicate a command as in 'shall not eat' (the fruit of the tree of knowledge) in Genesis 2:17, for instance (Agana 2018:105). In that case, Genesis 2:24 should actually read, 'Therefore a man should leave his father and mother, and cling to his wife, and they should become one flesh' (Du Preez 1999:32, [author's own emphasis]). Bowman (2015:6-7) seems to agree with this view when he declares that the translation in the future tense, which is prescriptive, is more reliable than that in the present, which is descriptive, because that is the version found in the Septuagint (LXX) which dates to the pre-New Testament eras. It therefore means that the prescriptive and covenantal understanding of marriage in Genesis 2:24 dates back to pre-New Testament eras. However, that the verse appears in the LXX in the future tense, does not make that translation more reliable than the translation in the present tense, because it appears also in the future tense in the MT. It seems that the recognition of Genesis 2:24 as an aetiology would help to resolve the argument on tense. As earlier mentioned, that the verse is an aetiology, implies that it is a comment added by a secondary author to explain a practice that had already been in existence. Certainly, such an explanation cannot be prescriptive but rather descriptive, which also implies that the appropriate tense cannot be future, but the simple present tense. It is most likely in realisation of this fact that many English versions thus render the verse as indicated above. Moreover, the argument based on tense is not helpful, because, oftentimes, the tense of a verb, for example in the MT, does not necessarily indicate its intended meaning. For example, in Genesis 2:10 the verb פרד [to divide] is used in niph'al imperfect and would have read 'will be divided', but it is clear that, in that context, the intended meaning is 'was divided'. Similarly, the third time the verb קרא [to call] appears in Genesis 2:19, it is in qal imperfect, but it is also clear that the intended meaning is 'called', not 'will call'. In this regard, Kelly (1992:130) may be correct when he describes how עזב is used in Genesis 2:24 as the 'frequentative use of the imperfect [which may express] repeated, habitual or customary actions, whether in the past, the present, or the future'. The point being made here, then, 
is that the intended meaning in Genesis 2:24 is in the simple present tense; and being an aetiology, it does not intend to prescribe any new norm on marriage, but simply explains marriage as practised at the time of writing. Therefore, if the verse is correctly rendered in the simple present tense, as found in the RSV and other versions mentioned above, it certainly does not give any idea of a command to all to marry. In other words, the perception that this text makes marriage mandatory for Christians, emanated from the mistranslation in the future tense.

\section{Corinthians}

1 Corinthians 7 opens with 'Now concerning the matters about which you wrote, it is well for a man not to touch a woman' (v. 1 - RSV). The Greek phrase $\mu \eta \alpha \pi \tau \varepsilon \sigma \theta \alpha$ is thus rendered by the RSV literally as 'not to touch', 'which connotes the idea of having sexual intercourse' (Ademiluka 2019:5). However, in this context, the term is better translated as 'not to marry' (as in the NIV and TEV) in view of 1 Corinthians 7:2, where the author advises everyone to marry 'because of the temptation to immorality' (RSV). Thus, Paul here responds to the Corinthian Christians' enquiries on matters having to do with the desire for abstinence from marriage (Baumert 1996:26). It can be deduced from the chapter that all categories of members of that church married people (1 Cor 7:1-5, 10-16), single people (vv. 6-9) and engaged people (vv. 25-40) - wanted answers to how to 'respond to the spiritual impulse towards abstinence' (Baumert 1996:27). Paul explains that the Christians should marry to avoid sexual immorality, as, in marriage, they can rightfully enjoy sexual intercourse (1 Cor 7:2-5). Paul wishes that 'all were as I myself am' (1 Cor 7: - RSV), ${ }^{4}$ but as they may not have the gift of self-control as he has, they may go ahead and marry (vv. 7-9).

There are divergent views on what Paul wishes in 1 Corinthians 7: 7. Some argue that what he wishes for all is not the unmarried state, but continence. According to Ellicott's Commentary for English Readers, Paul's 'words do not mean that the Apostle wished that everyone was unmarried, but that everyone had the same grace of continence which he himself was endowed with' (Bible Hub 2004-2020). As another source puts it, Paul:

$[W]$ ould be glad if all people had control over their passions and propensities as he had ... and could abstain from marriage when circumstances of trial, etc., would make it proper. (Barnes' Notes on the Bible, cited in Bible Hub 2004-2020)

Thus, according to this source, the wish for self-control is to enable one to abstain from marriage if occasion calls for abstinence. This view finds support in the Adam Clarke Commentary 'that Paul wished that all [the members of the Corinthian] church were unmarried like himself [for the sake of] the necessities of the Church' (Studylight.org 2001-2020c). It is therefore plausible to suggest that the wish for selfcontrol is to serve the purpose of abstinence from marriage, which, in turn, would enable the celibate to serve the church better. Hence, it is incorrect to say that what Paul wishes in 1 Corinthians 7:7 is not celibacy, but self-control, because in this context, the two are inseparable. It may be correct, then, to say that Paul 'had tasted the [value] of the celibate life, and was desirous that others should' taste it (Bengel's Gnomen, cited in Bible Hub 2004-2020). For Paul, then, it is 'not that marriage is a $\sin$ [1 Cor 7: 28], but celibacy is preferable' (Moss \& Baden 2015:171). In the words of King (2011):

[T] he single life is better than the married life, but the married life is better than fornication ... Paul's advice, then, is that those who can handle celibacy and not be tempted by fornication should opt for the single life, but those who do not possess the necessary self-control should opt for marriage so as to avoid fornication. (p. 5)

Some interpreters observe that Paul prefers celibacy for Christians on two grounds (e.g. King 2011:5-7; Reed 2013:73). Firstly, it is better to remain single in view of the imminent eschaton (1 Cor 7: 26), and secondly, celibacy will enable them to be fully devoted to God's service (vv. 32-34). In 1 Corinthians 7:26, Paul says there is a 'present crisis' ( $\varepsilon v \varepsilon \sigma \tau \omega \sigma \alpha v$ $\alpha v \alpha \gamma \kappa \eta v)$, which is explained in verse 31 in terms of 'the form of this present world ... passing away' (RSV). But it should be noted that the reference to the eschaton here is applicable only to the betrothed members of the Corinthian church (1 Cor 7:25-40). Paul says that, in view of the imminent end of the world, ${ }^{5}$ it is preferable for them not to consummate marriage with their partners; however, they are free to do as they wish (Ademiluka 2019:8; King 2011:6). Moreover, Paul has made it clear that he was single, which could not be linked to his view of the eschaton; and throughout the chapter, he does not hide his preference for the celibate life for Christians (1 Cor 7:1,7-8, 38). Therefore, the principal reason for Paul's preference is found in 1 Corinthians 7:32-34. Celibacy is preferable for Christians, because it will enable them to be fully devoted to God's service, free from worldly anxieties.

Nonetheless, Paul's preference for celibacy over marriage is explicable in the context of later stoicism and Jewish asceticism. His idea that marriage was necessary for those who could not control themselves sexually 'and would need release echoed the sentiment of ancient medics and Romans in general, for whom an excess of blood boiled sperma required a legitimate outlet' (Moss \& Baden 2015:189). Hence, in choosing marital affairs over the patronage of prostitutes, 'Paul blended together biblical morality and Stoic sexual ethics or Jewish asceticism' (Moss \& Baden 2015:190). Plato's well-known idea of marriage and sex as a distraction must also have influenced Paul's relation of matrimony to worldly anxieties (Moss \& Baden 2015:190) - the suggestion which seems to be reflected by Keener (1993) when he states that:

$[A]$ number of groups of philosophers and minor [Jewish] religious sects ... advocated celibacy or the rejection of marriage. [To them] marriage is a distraction and should never be undertaken by the wise man except in the rare instances where one might find a spouse equally devoted to the philosophic life. (p. 466)

5.Some claim that by 'the present crisis', Paul points to a historical crisis in grain shortages that led to widespread famine throughout the Roman Empire at that time (see Reed 2013:77). 
Although Paul's recommendation of celibacy seems to be particularly for devotion to God's work, it proves that the Bible does not make marriage an obligation for all, which is in harmony with the conclusion reached on the Genesis texts examined above. This conclusion is also in keeping with the larger biblical picture [which presents] marriage as optional, on practical (1 Cor 7:2, 9, 26), personal (v. 39), religious (vv. 32 -34), and missiological (Matthew 19:12) grounds' (Agana 2018:107). From the biblical perspective, then, marriage becomes a choice, and not a duty. Therefore, Nigerian Christians who have to remain single due to their inability to find spouses have not disobeyed any biblical injunction. More importantly, with this understanding of the biblical perspective on marriage, the desperation for marriage among Nigerian Christian women is not only unnecessary, but also unbiblical.

\section{Conclusion and recommendation}

Of recent in Nigeria, the downward turn of the economy, among other factors, has led to a considerable increase in the rate of involuntary singlehood with its attendant constraints, especially for women. An additional burden for Christian singles is the feeling of guilt due to the perception that the Bible commands everyone to marry, relying particularly on Genesis 1:28 and 2:18, 24, but often not taking cognisance of Paul's preference for celibacy in 1 Corinthians 7. To this end, singlehood constitutes enormous constraints for Nigerian Christians. This article found that the Genesis passages, from which is derived the perception that marriage is obligatory for all, are largely misunderstood. Rather than commanding marriage for everyone, they are in harmony with 1 Corinthians 7 and the larger biblical picture which makes marriage optional. Nigerian Christians therefore need a reorientation in their attitude towards marriage, which is where the church still has a lot of work to do. In its pastoral responsibility, the church has to imbibe the biblical perspective that virginity is as honourable as marriage for Christians. To inculcate this teaching in its members, preaching should begin to be more accommodating to involuntary singles. For instance, when the youth are being advised on getting suitable mates, such advice should be balanced with the admonition that singlehood is equally valuable. In those denominations where women are ordained into the leadership cadre, there must not be discrimination against single women; they 'must also be allowed to take leadership roles just like all other women' (Baloyi 2010:740). They must be made to participate in all church programmes like their male counterparts and married women. The church must begin to include in all its manuals and programmes the teaching that both marriage and celibacy are equally acceptable before God.

\section{Acknowledgements Competing interests}

The author declares that they have no financial or personal relationships that may have inappropriately influenced them in writing this article.

\section{Author's contribution}

S.O.A. is the sole author of this research article.

\section{Funding information}

This research received no specific grant from any funding agency in the public, commercial or not-for-profit sectors.

\section{Ethical considerations}

This article followed all ethical standards for research without direct contact with human or animal subjects.

\section{Data availability}

The authors confirm that the data supporting the findings of this study are available within the article.

\section{Disclaimer}

The views and opinions expressed in this article are those of the author and do not necessarily reflect the official policy or position of any affiliated agency of the author.

\section{References}

Adamolekun, T., 2006, 'Marriage and divorce from Christian perspective: An examination of Pauline corpus', in S.O. Abogunrin (ed.), Biblical view of sex and sexuality from African perspective, pp. 138-150, Nigerian Association for Biblical Studies, Ibadan.

Ademiluka, S.O., 2019, 'Reading 1 Corinthians 7:10-11 in the context of intimate partner violence in Nigeria', Verbum et Ecclesia 40(1), 1-10. https://doi. org/10.4102/ve.v40i1.1926

Agana, A., 2018, 'Is marriage for all? A theological reflection on the grammar of Genesis 2:18, 24', Asia-Africa Journal of Mission and Ministry 17, 90-110. https:// doi.org/10.21806/aamm.2018.17.05

Agazue, C., 2015, The role of a culture of superstition in the proliferation of religiocommercial pastors in Nigeria, Author House, Bloomington, IN.

Agazue, C., 2016, "'He told me that my waist and private parts have been ravaged by demons": Sexual exploitation of female church members by "prophets" in Nigeria', Dignity: A Journal on Sexual Exploitation and Violence 1(1), 1-16. https:// doi.org/10.23860/dignity.2016.01.01.10

Ahiamadu, A., 2010, 'A postcolonial critical assessment of the imago dei in Gen 1:26-28 in Nigerian perspective', Scriptura 103(1), 97-106. https://doi.org/10.7833/ 103-0-591

Baloyi, M.E., 2010, 'Pastoral care and the agony of female singleness in the African Christian context', In die Skriflig 44(3 \& 4), 723-742. https://doi.org/10.4102/ids. $\mathrm{v} 44 \mathrm{i} 3 / 4.169$

Baumert, N.S.J., 1996, Woman and man in Paul: Overcoming a misunderstanding, transl. P. Madigan \& L.M. Maloney, Michael Glazier, Collegeville, MN.

Bible Hub, 2004-2020, 'Commentaries on 1 Corinthians 7:7', Bible Hub, viewed 15 June 2020, from https://biblehub.com/commentaries/1_corinthians/7-7.htm.

Birch, B.C., Brueggemann, W., Fretheim, T.E. \& Petersen, D.L. (eds.), 2005, A theologica introduction to the Old Testament, 2nd edn., Abingdon, Nashville, TN.

Bowman, R.M., Jr., 2015, 'Genesis and the definition of marriage: Monogamy and polygamy in biblical history and ethics', Academia, viewed 07 March 2019, from https://www.academia.edu/18438877/Genesis_and_the_Definition_of Marriage_Monogamy_and_Polygamy_in_Biblical_History_and_Ethics.

Cole, S.J., 1995, 'God's design for marriage (Genesis 2:18-25)', Christian Family Living, viewed 08 December 2019, from https://bible.org/seriespage/lesson-2-god-sdesign-marriage-genesis-218-25.

Daube, D., 1977, The duty of procreation, Edinburgh University Press, Edinburgh.

Davidson, R., 1973, The Cambridge Bible commentary on the New English Bible: Genesis 1-11, Cambridge University Press, Cambridge.

Davidson, R.M., 1988, 'The theology of sexuality in the beginning: Genesis 1-2', Andrews University Seminary Studies 26(1), 5-21.

Du Preez, R., 1999, 'The God-given marital mandate: Monogamous, heterosexual, interfaith', Journal of the Adventist Theological Society 10(1-2), 23-40.

Efthimiadis-Keith, H., 2010, 'Genesis 2:18-25 from a Jungian and feministdeconstructionist point of view', Old Testament Essays 23(1), 44-65.

Hartley, J.E., 1980, 'צלע', in R.L. Harris, L.A. Gleason Jr. \& B.K. Waltke (eds.), Theological wordbook of the Old Testament, 2 vols., p. 768, Moody Publisher, Chicago, IL. 
Hooke, S.H., 1982, 'Genesis', in M. Black \& H.H. Rowley (eds.), Peake's commentary on the Bible, pp. 173-206, Van Nostrand Reinhold, Wokingham.

Igbokwe, C., 2011, 'Polygamy pastor under fire', NBF News, viewed 18 December 2019, from http://www.nigerianbestforum.com/blog/polygamy-pastor-underfire/.

Isiugo-Abanihe, U., 2000, 'Female age at marriage and proportions marrying in Nigeria', African Population Studies 15(2), 43-65.

Jerome, O.M., 2016, 'Detachment as a prerequisite for a happy family: A study of Genesis 2:24', Mediterranean Journal of Social Sciences 7(4), 526-532. https:// doi.org/10.5901/mjss.2016.v7n4p526

Keener, C.S., 1993, The IVP Bible background commentary: New Testament, IVP, Nottingham, IL.

Kelly, P.H., 1999, Biblical Hebrew: An introductory grammar, Eerdmans, Grand Rapids, MI.

King, D.D.M., 2011, 'The marriage debate and 1 Corinthians 7', MA thesis, lliff School of Theology, Denver, CO.

Koehler, L. \& Baumgartner, W., 2000, The Hebrew and Aramaic Lexicon of the Old Testament, Brill, Leiden.

Koons, C. \& Anthony, M., 1991, Single adult passages: Uncharted stories, Baker, Grand Rapids, MI.

Kyalo, P., 2012, 'A reflection on the African traditional values of marriage and sexuality' International Journal of Academic Research in Progressive Education and International Journal of Acad
Development 1(2), 211-219.

Luck, W., 2009, 'Cohesiveness in the marriage union - (Genesis 2:24)', Bible.org, viewed 03 June 2020, from https://bible.org/seriespage/1-cohesivenessmarriage-union-genesis-224.

Lussier, E., 1956, 'Adam in Genesis 1, 1-4, 24', The Catholic Biblical Quarterly 18(2), 137-139.

Magnuson, K.T., 2000, 'Marriage, procreation and infertility: Reflections on Genesis', The Southern Baptist Journal of Theology 4(1), 26-43.

Makinde, T., 2004, 'Motherhood as a source of empowerment of women in Yoruba culture', Nordic Journal of African Studies 13 (2), 164-174.

Manasra, N.M., 2003, 'The effect of remaining unmarried on self-perception and mental health status: A study of Palestinian single women', PhD thesis, De Montfort University, Leicester.

Mbiti, J.S., 1969, African religions and philosophy, Heineman, London.

Mbiti, J.S., 1991, Introduction to African Religion, Heinemann, Ibadan.

Merril, E.H., 1991, 'A theology of the Pentateuch', in R.B. Zuck (ed.), A biblical theology of the Old Testament, pp. 7-113, Moody Press, Chicago, IL.

Monroe, K. \& Monroe, P., 2005, 'The Bible and pain of infertility', Journal of Biblical Counseling 23(1), 50-58.

Moss, C.R. \& Baden, J.S., 2015, Reconceiving infertility: Biblical perspectives on procreation and childlessness, Princeton University Press, Princeton, NJ.

Murray, J., 1957, Principles of conduct: Aspects of biblical ethics, Eerdmans, Grand Rapids, MI.

National Population Commission (NPC), 2009, Nigeria demographic and health survey 2008, NPC, Abuja.

Ntoimo, F.C., 2012, 'Prevalence, determinants and consequences of spinsterhood in Lagos, Nigeria', PhD thesis, University of Ibadan.

Ntoimo, L.F.C. \& Isiugo-Abanihe, U., 2013, 'Patriarchy and singlehood among women in Lagos, Nigeria', Journal of Family Issues 35(14), 1980-2008. https://doi. org/10.1177/0192513X13511249

Oderinde, O.A., 2013, 'A socio-religious perspective of late marriage and stigmatization of single adults and its impact on the Church in Nigeria', Review of European Studies 5(4), 165-171. https://doi.org/10.5539/res.v5n4p165
Oforchukwu, J.I., 2010, 'A biblical and theological study (analysis) of marriage and divorce among Igbo Catholic Christians (Nigeria)', MA thesis, South African Theological Seminary, Sandton.

Ojua, T.A., Lukpata, F.E. \& Atama, C., 2014, 'Exploring the neglect of African family value systems and its effects on sustainable development', American Journal of Human Ecology 3(3), 43-50. https://doi.org/10.11634/216796221403585

Okonofua, F.E., Harris, D., Odebiyi, A., Kane, T. \& Snow, R.C., 1997, 'The social meaning of infertility in southwest Nigeria', Health Transition Review 7, 205-220.

Omeike, H.U., 2017, 'A theological retrieval of communal parenting as a moral response to baby stealing and childlessness in Nigeria', ThM thesis, Saint John's University, Collegeville, MN.

O'Reggio, T., 2012, Martin Luther on marriage and family, Faculty Publications, viewed 03 June 2020, from http://digitalcommons.andrews.edu/church-history-pubs/20.

Reed, D.A., 2013, 'Paul on marriage and singleness: Reading 1 Corinthians with the Augustan marriage laws', PhD thesis, Toronto School of Theology, Toronto.

Ryan, M.A., 2005, 'Faith and infertility', Christian Reflection, pp. 65-74, The Centre for Christian Ethics, viewed 22 March 2020, from https://www.baylor.edu/ifl/ christianreflection/CloningarticleRya.pdf.

Schultz, C., 1980, 'עזר', in R.L. Harris, L.A. Gleason, Jr. \& B.K. Waltke (eds.), Theological wordbook of the Old Testament, 2 vols., pp. 660-662, Moody Theological wordbook
Publisher, Chicago, IL.

Shuzhuo, L., Qunlin, Z., Xueyan, Y. \& Attané, I., 2010, 'Male singlehood, poverty and sexuality in rural China: An exploratory survey', Population 65(4), 679-693. https://doi.org/10.3917/pope.1004.0679

'Singlehood', 2020, Merriam-Webster.com dictionary, Merriam-Webster, viewed 06 June 2020, from https://www.merriam-webster.com/dictionary/singlehood.

Studylight.org, 2001-2020a, 'Commentary on Genesis 2:18', Studylight.org, viewed 12 June 2020, from https://www.studylight.org/commentary/genesis/2-18.html.

Studylight.org, 2001-2020b, 'Commentary on Genesis 2:24', Studylight.org, viewed 13 June 2020, from https://www.studylight.org/commentary/genesis/2-24.html.

Studylight.org, 2001-2020c, 'Commentaries on 1 Corinthians 7:7', Studylight.org, viewed 15 June 2020, from https://www.studylight.org/commentary/ 1-corinthians/7-7.html.

Taylor, R.B., 2010, 'The principles of marriage: Genesis 2:24-25', WLDCOMBE Baptist Church, pp. 1-3, viewed 11 June 2020, from https://www.widcombebaptistchurch. org/assets/media/sermons/notes/2010-02-07-am.pdf.

Uchendu, V.C., 1965, The Igbo of southeast Nigeria, Holt, Rinehart and Winston, New York, NY.

Uzoma, E.F. \& Okoye, M.K., 2010, 'Challenges and implications of Genesis 2:18-24 on same-sex marriage for the contemporary society', Journal of Religion and Human Relations 1(3), 82-93.

Warner, M., n.d., 'Marriage and the attraction between men and women in Genesis 2:24', Bible Odyssey, viewed 17 November 2019, from https://www.bibleodyssey. $\mathrm{org} / \mathrm{en} /$ passages/related-articles/marriage-and-the-attraction-between-menand-women-in-genesis-2-24.aspx.

Wenham, G.J., 1987, Genesis 1-15: Word Biblical Commentary, Word Books, Waco, TX.

Wenham, G.J., 1994, 'Genesis', in D.A. Carson, G.J. Wenham, J.A. Motyer \& R.T. France (eds.), New Bible commentary, pp. 54-91, IVP, Nottingham.

White, J., Jr., 2009, 'Marriage and family life', in H.J. Selderhuis (ed.), The Calvin handbook, pp. 455-456, Erdmans, Grand Rapids, MI.

Zwang, J., 2004, 'Perceptions and attitudes towards late marriage and premarital fertility in rural South Africa: A study on social changes and health risks among young adults', IFAS working paper series/Les Cahiers de I' IFAS, 2004, 4, 61p, hal00786290. 